\title{
Zimbabwe's Elections: A Legitimate Ritual of ZANU PF
}

\author{
Emaculate Mvundura \\ Lecturer in the Department of Humanities \\ Africa University, P O Box 1320, Mutare \\ Zimbabwe
}

\begin{abstract}
Elections are often thought of as the heart of the political process (Heywood, 2007, p. 247). In principle, elections are mostly viewed as democracy in practice - a means through which the people can control their government and keep it in check. In return, elected leaders will always be conscious of the fact that their stay in power is primarily premised upon their ultimate satisfaction of the electorate who in essence, wield power. In democratic political systems, elections are an important feature of public participation in choosing the individuals and groups that will rule them (Makumbe, 2006, p. 1). However, majority of African countries' ruling parties mostly hailing from governments led by former liberation movements have mastered and perfected the art of manipulating electoral systems with the primary objective of deceiving the people into believing that they govern themselves. As such, whereas there is absolute defiance of the proper conduct of a free and fair election, authoritarian governments still regard the legitimate stay on power as critical especially power retention attained through an election, regardless of how sham its conduct could be. Such has been the case in Zimbabwe - a state whose electoral history has been marred with violence, electoral fraud, and prolonged stay in power by the ruling party. Under the given circumstances it is challenging to dismiss as inaccurate, assertions that in Zimbabwe just like many African states, elections are still only viewed as a viable means to retain legitimacy of the otherwise illegitimate authoritarian regimes.
\end{abstract}

Keywords: elections, legitimacy, independence, one-party, electoral systems.

\section{Methodology}

This paper is mainly reflective in its approach, although reference is made to various reports of surveys conducted in Zimbabwe by a variety of institutions. As such, the methodology that formed the basis of this paper was mostly qualitative. Documentary review of books, journal articles, press statements, media publications and research reports sought to provide the background and statistical data for analysis and synthesis. The paper is thus a broad brush, based on a critical filed opinion survey, which builds on the existing literature and adopts a multidisciplinary approach.

\section{Tracing the legacy of electoral violence and fraud in Zimbabwe}

The underlying cause of Zimbabwe's political culture of electoral violence and electoral fraud lies in the means at which Zimbabwe attained its statehoodi. Following a deadlocked struggle between Ian Smith's Unilateral Declaration of Independence (UDI) ${ }^{\text {ii }}$ government and liberation movements of the Zimbabwe African National Union (ZANU) as well as the Zimbabwe African People's Union (ZAPU). The erstwhile colonial master - the British Government, brokered interparty independence talks which culminated into the Lancaster House Conference between September to December 1979 (Rusero, 2016).

Although ZANU swept the majority of seats by garnering 57 seats in Parliament, the machinations indulged by the party to marshal electoral support has often been ignored right from the start. Firstly, the party dispatched its political commissars in rural areas who became critical agents of campaigning. As other observers like Flower (1987) note, ZANU cultivated a significant threat that the war could continue if those waging it were not voted into power. These intimidation tactics by ZANU often culminated into killings, rape, robbery, and stock-theft, which left the villagers shell shocked and traumatised for the umpteenth time.

Secondly, Flower (1987, p. 255) confessed that Rex Nhongo, the Commander of ZANU's military wing - the Zimbabwe African National Liberation Army (ZANLA), had instructed 7000 or more guerrillas to ignore the Lancaster House cease-fire agreement of 1979 and hide their weapons throughout the central and eastern electioneering areas, to be used to 'persuade' the people to vote for ZANU (PF). Thus the 1980 general elections were flawed by irregularities, violence, and intimidation patterns that have persisted through-out the postindependence era.

Though the ruling party structures have allowed for a degree of participation, that participation has been rigidly circumscribed (United States Institute of Peace, 2003, p. 1). Such circumstances certainly did not sow good seeds of the popular democratic culture of creating an enabling environment for the conduct of free and fair elections which could effectively be used to gauge legitimacy and popularity of the ruling ZANU PF. 
In addition to the above, the perpetual continuation of the binary characterisation of citizens in the post-independent Zimbabwean State has not been helpful. In ZANU PF's understanding citizens are enemies or comrades, patriots, or sell-outs (Ranger, 2010). Likewise, those people, provinces, and regions where the party draws support are progressive revolutionaries, comrades, and patriotic citizens whereas those opposed to it are visionless enemies and dangerous sell-outs that are bent to reverse gains of the liberation struggle. Such framing has contributed much to the continued division and strife among Zimbabweans in the post-colonial trajectory. Its devastating effects were the clear manifestation of the Gukurahundi iii which took place between 1982-1987, where citizens amounting to 20 000 people were brutally murdered at the hands of a specialised North-Korean trained unit of the Fifth Brigade, (CCPJ, 1997). The ZANU PF- led government, claimed the Fifth Brigade was aimed at dealing with dissidents deployed by Apartheid South Africa to destabilise a newly elected black majority government in Zimbabwe.

Although chief among the motives of waging the protracted liberation struggle was the clamour for the "one man one vote", it would appear that the post-colonial state of Zimbabwe learnt nothing and forgot nothing from the predecessor colonial state. In Rhodesia, there was absolutely no universal suffrage given that voting was only a preserve of the minority white settlers (Rusero, 2016). The colonial state was characterised by the absence of black participation in governance processes. The electoral process did not involve the black majority. Similarly, in the post-colonial state, almost four decades after attaining independence, many voters are still marginalised and disenfranchised.

As Mamdani (1990, p. 47) argues, “...the colonial state was simply inherited at independence [and] that the independent state was a simple continuation of its predecessor". However, the paper still asserts that elections critically matter in Zimbabwe just like any given society primarily because their central functions include: recruiting politicians, making governments, providing representation, influencing policy, educating voters, building legitimacy, and strengthening elites, (Heywood, 2007, pp. 255-266).

\section{The first decade of Independence and the failed attempt of one-partyism}

Observers of the Zimbabwe political scene are likely to assume that Zimbabwe was, until the 1990s, a one-party state chiefly because for the better part of the first decade of independence the ZANU (PF) political leadership was openly advocating for a Socialist one-party state. According to Sithole and Makumbe (1997, p. 122), Zimbabwe was indeed a de facto one-party state. Even though Zimbabwe has never foreclosed multi-party electoral opportunities, the power structure had limited such opportunities by maintaining and perpetuating one-party psychology for the first eleven years of independence (Sithole and Makumbe, 1997, pp. 122). In essence, ZANU PF functioning as a hegemonic party attempted to blur lines between party and state and to limit political activism outside the party. Since the independence elections of 1980 and particularly during the first decade, the ZANU (PF) party held electoral hegemony. Also, ZANU (PF)'s complicated history as a splinter liberation movement from ZAPU sowed seeds of its unapologetic skeptism to opponents whom they have never perceived as rivals but real enemies.

As such, even Mugabe's attempt to forge unity with ZAPU and its leader Joshua Nkomo through morphing a government of national unity in 1980 after incorporation of ZAPU cadres as cabinet ministers was very short-lived. With ZAPU outside government following the dismissal of Nkomo and his colleagueson the accusation of a coup plot, ZANU (PF)'s uneasiness was very evident through panic and unleashing a militia to crush dissent and dissident activities in the Midlands and Matabeleland, the very strongholds of ZAPU's support base. The dissident activities in Matabeleland and parts of Midlands were viewed by ZANU (PF) as a challenge to and a test of the party's will and capacity to rule, (Sithole \& Makumbe, 1997, pp. 122). This challenge reinforced the need for elite cohesion up to the merger of these two leading nationalist parties in 1987, following the signing of the Unity Accord that 'enjoined' ZANU (PF) AND PF-ZAPU giving birth to a 'unified' ZANU PF.

During the same year, Zimbabwe amended its constitution and introduced an executive presidency that would be elected directly by the people every six years starting from 1990, (Sithole \& Makumbe, 1997, pp. 131). Before that, Zimbabwe had a titular president who was elected by an electoral college comprising the Senate (scrapped in 1987 but later re-introduced in 2005 for political expediency) and Parliament. The office of the prime minister which previously had executive powers was abolished. This was another effort to morph the idea of the one-party state into reality.

However, in 1990 one of the founding members of ZANU PF and its outspoken secretary-general, Edgar Tekere heavily resisted the party's proposals of a One-Party State and after being expelled from the party went on to form the Zimbabwe Unity Movement (ZUM) that contested ZANU PF in the 1990 general elections. ZUM gained its strength from the disclosure of widespread corruption scandals, the deteriorating economy and increasing unemployment, which mobilised against ZANU PF, the very people President Mugabe had proclaimed as favoured by the government, particularly students and trade unions in the urban areas, (Cowen \& Laasko, 2002). 
Thus, the 1990 elections, with ZUM fielding up candidates throughout the country, provided people with an opportunity to vote against the ruling party and its plans to establish a One-Party State, (Cowen \& Laasko, 2002). ZUM's attempts to hold public rallies were almost always systematically rejected. Although the lifespan of ZUM was short-lived, it laid the foundation of challenging ZANU PF's monotheistic hegemony, (Cowen \& Laasko 2002). It also marked the death of the feasibility and prospects of a one-party state.

\section{The second decade of independence - ZANU PF's electoral honeymoon}

Following the abolishment of the office of the prime minister and the introduction of an executive presidency, Zimbabwe's first presidential elections were held in 1990. There were two candidates in this election, ZANU PF's Robert Mugabe and ZUM's Edgar Tekere. As in the 1990 parliamentary elections held simultaneously with the presidential election, ZANU PF and Mugabe won a crushing victory with Mugabe winning $83 \%$ of the valid votes compared to Tekere's 17\% (Moyo, 1992, p. 166). This heralded an era of little and ineffective opposition to Mugabe's rule. With Zimbabwe under ZANU PF appearing to be stable and politically calm, it won many international friends and support.

Chimanikire (2003, pp. 179 -195) states that Harare became Southern Africa's diplomatic hub and a key player in the Front-Line States' fight against apartheid and colonialism. This foreign policy stance resulted in Zimbabwe's military intervention in Mozambique and Angola, which were threatened by civil wars. Zimbabwe became actively involved in the promotion of self-determination by putting regional arrangements such as SADC and the OAU into the global spotlight (Nyakudya, 2013, pp. 83-84). Klotz (1993, p. 265) states that Mugabe's condemnation of racism in South Africa and Namibia shaped Zimbabwe's foreign policy on non-racialism. According to Alao (2012, p. 116), Zimbabwe extended a sanctuary to black movements such as the African National Congress (ANC) and the Pan Africanist Congress (PAC).

As such, the evolution and subsequent formulation of Zimbabwe's foreign policy after independence premised on the legacy of the liberation struggle, which Mugabe managed to deeply entrench Pan-Africanist sentiments resonated well within a region influenced by the anti-imperialist and anti-colonial ideology of governments led by former liberation movements (Phimister and Raftopolous, 2004, p. 385). In the region, six former liberation movements are in power.That is Zimbabwe's ZANU PF, South Africa's African National Congress (ANC), Mozambique's Front for the Liberation of Mozambique (FRELIMO), Angola's Popular Movement for the Liberation of Angola (MPLA) as well as Namibia's South West People's Organisation (SWAPO) and Tanzania's Chama Cha Mapinduzi (CCM) (Nldovu-Gatsheni, 2010). Mugabe has mainly capitalised on such regional historical dynamics to drum up support against his adversaries.

In the 1996 presidential elections, there were over a dozen political parties on the Zimbabwean political landscape. However, most of them boycotted the elections which they claimed were being held on an uneven playing field (Sithole \& Makumbe, 1997, p. 131). With the increased voter fatigue evidenced by a decline in voter turnout, it became clear that ZANU PF would at least enjoy political and electoral hegemony for the better part of the second decade after independence.However, with the shifting dynamics of the economic landscape, following the adoption of the Bretton Woods institutions' Economic Structural Adjustment Programme (ESAP) as well as the unbudgeted payouts of $\$$ Z50 000 gratuities to each war veteran as a compensation prize of participating in the liberation struggle, early signs of a waning ZANU PF support base could easily be detected.

Also, Mugabe's unilateral decision to intervene in the Democratic Republic of Congo (DRC) on the side of the beleaguered Laurent Kabila in 1998 accelerated the pace at which the economy was receding down the precipice. These blundered decisions of sacrificing a stable economy on the altar of political expediency by ZANU PF became the prologue of the party's rejection by the entire masses and dwindling legitimacy outlook it had on the international community scale.

\section{The new millennium and the incipient decline of ZANU PF's electoral hegemony}

Government's increased intolerance and defiance of citizens' demands for a better standard of living, employment creation and abandonment of the costly DRC War did not augur well with the trade unions, precisely the Zimbabwe Congress of Trade Unions (ZCTU), the students under the banner of Zimbabwe National Students Union (ZINASU), farmers under the banner of Commercial Farmers Union (CFU) as well as some sections of the business community and the middle class mostly comprising of teachers, nurses and lecturers. These groups cascaded into a formidable alliance that was critical of the government's policies. This subsequently gave birth to the Movement for Democratic Change (MDC) and Morgan Tsvangirai; former ZCTU secretary-general became the president of the new political party, deputised by Gibson Sibanda who was ZCTU's president during Tsvangirai's tenure as secretary-general. Other leaders of the MDC were drawn from the civil society and the students' organisation of ZINASU. 
The opposition MDC was officially launched on September 12, 1999, at Rufaro Stadium in Harare, the very same place Zimbabwe celebrated its independence from Britain on April 18, 1980. It became evident that the newly formed MDC which had an enthusiastic appeal to the urban and town dwellers around the country would pause as the most significant political threat ZANU PF had ever faced in the post colony.In 2000 the MDC came out with full political force, winning 57 of the 120 contested seats of Parliament in the June 2000 parliamentary elections. This was a symbolic victory given that the party was only nine months old. Before this political development, in February of the same year, majority of Zimbabweans led by the National Constitutional Assembly (NCA), a crusade alliance of the MDC had rejected the ZANU PF proposed draft constitution to replace the Lancaster House Constitution. This was perceived as a litmus test to ZANU PF legitimacy, and the famous No Vote triumph was regarded as a victory for the MDC.

ZANU PF responded emotionally to MDC's victory, labelling them agents of the West up for an illegal regime change project, with the MDC's president himself labelled a puppet of Britain. The party then embarked on a land reform programme that was dubbed the "fast track" land reform, perceived as another war, coded the Third Chimurenga $a^{i v}$. The execution of the land reform was spearheaded by the war veterans - former soldiers of the 1970s liberation struggle. As such, it turned out to be an ugly platform of human rights abuse that was condemned by the international community. Other elections came in 2002 and 2005, but the level playing field was uneven. The March 2002 presidential elections were conducted in an environment of strong polarisation, political violence and an election administration with severe shortcomings.

ZANU PF was declared the winner of the elections amid widespread local and international observer claims that the election was "unfree and unfair" (United States Institute of Peace, 2003, p. 1). The MDC mounted a court challenge to the result and international actors imposed "smart sanctions" against the ZANU PF regime. Tsvangirai, the leader of the opposition MDC, and two other leaders were charged with treason for allegedly plotting to assassinate President Mugabe. After a June-2 stay-away called by MDC, Tsvangirai was arrested and detained under a second treason charge, this time for "seeking to overthrow a democratically elected president violently." Mugabe often ignored attempts made by regional players such as Nigeria and South Africa to broker talks between ZANU PF and MDC on the basis that he could not talk to people (MDC) who did not consider himself a legitimate president. The stance Mugabe took is an indicator of how legitimacy by any cost matter to the survival of the ZANU PF polity.

The security sector consisting of the Central Intelligence Organisation (CIO) the Army, the Air Force, the Police and the Prisons had on several counts maintained that it would never cast its allegiance and obedience to anyone whose motives exhibit 'a threat to Zimbabwe's national values'. A couple of weeks before the conduct of the 2002 presidential elections, the then Commander of the Defence Forces Vitalis Zvinavashe made headlines when he held a press conference where he proclaimed that the security forces would not support or salute anyone with a different agenda that threatened the very existence of Zimbabwe's sovereignty, the country and its people.

We wish to make it very clear to all Zimbabwean citizens that the security organisations will only stand in support of those political leaders who will pursue Zimbabwean values, traditions, and beliefs. Of which thousands of lives were lost in the pursuit of Zimbabwe's hard-won independence, sovereignty, territorial integrity, and national interests. To this end, let it be known that the highest office in the land is a strait jacket whose occupant is expected to observe the objectives of the liberation struggle. We will therefore not accept, let alone support or salute, anyone with a different agenda that threatens the very existence of our sovereignty (Zvinavashe, quoted in Tendi, 2010).

The statement was perceived as a direct aim at Tsvangirai who did not participate in Zimbabwe's liberation struggle. To Zvinavashe, elections not won by Mugabe were not acceptable as he was the only one with the legitimate support of the security sector. A pattern of intimidation and violence marred the run-up to the election. Even though incidents were reported from both sides, the evidence clearly showed that in the vast majority of cases, the ruling ZANU PF party was to blame. Observers have documented numerous reports of harassment and assault of opposition officials, members and supporters and their homes. Opposition offices were also attacked in several places.

At a state funeral, Mugabe openly attacked the MDC, accusing the party of terrorism, comparing himself to Hitler, and warning that "those who play with fire will not just be burned but will be consumed by that fire."

It is the above kind of thinking which meant that ZANU PF was still not prepared for any form of rivalry and thus viewed an election as a mere formality. To ZANU PF, as reflected by its leader's utterances, opposing ZANU PF was likened to playing with fire and had consequences. Venturing into opposition politics would thus be done by citizens at their detrimental peril. The election administrators, both the bodies administering the elections and those supervising them, formed part of the executive structure, lacking convincing independence and integrity. The contesting parties' only involvement was through their polling and election agents. Polling agents for the opposition were in many instances harassed or intimidated by supporters of the ruling party or the police and often absented themselves during actual voting days fearing for their lives. 
With laws typical of the erstwhile colonial regime in place, the electoral climate of 2002 was far from favourable and permissible to yield any proximity to the conduct of a credible free and fair election. The government enacted laws that sought to legitimise and legalise its behaviour towards opponents. The notorious Public Order and Security Act (POSA) and the retrogressive Access to Information and Protection of Privacy Act (AIPPA) both passed in early 2002 placed restrictions upon citizens' fundamental rights and became unpopular but effective instruments to close any space for the opposition to manoeuvre. POSA substantially constrained the free exercise of rights to assembly, speech, and association, whilst public meetings had to be authorised by the police, whilst debating on political issues was strictly prohibited (United States Institute of Peace, 2003, p. 4). AIPPA whilst disguised as an empowering instrument to grant information presented numerous obstacles to press freedom and was used severely to curtail access to, and presentation of information in Zimbabwe (United States Institute of Peace, 2003, p. 5)

In 2008 harmonised elections were held and the presidential race had three contesters who were Robert Mugabe of ZANU PF, Morgan Tsvangirai of the MDC as well as Simba Makoni who stood as an independent candidate following his defection from ZANU PF. The elections were inconclusive because in the first round President Mugabe was defeated by Tsvangirai. However, he did not garner enough votes amounting to 51 percent as stipulated by the Constitution to form a government. This paved the way for a run-off slated for June 27, 2008, but citing persecution of his supporters, Tsvangirai pulled out of the race. The Africa Union (AU) and the Southern Africa Development Community (SADC) intervened and recommended the formation of a coalition government. The inter-party talks were mediated by SADC-appointed former South African president Thabo Mbeki. The talks were concluded on September 15, 2008, following the investiture of the Global Political Agreement (GPA) signed by President Mugabe and the two MDC formations which since 2005 had splintered into two groups following a dispute to contest the 2005 senatorial elections. The Government of National Unity commenced on February 9, 2009, after Tsvangirai's swearing-in as Prime Minister together with Arthur Mutambara and Thokozani Khupe as Deputy Prime Ministers. Governmental ministries were shared under agreed proportions stipulated in the GPA.

\section{The SADC region's electoral framework}

It is a paradox that SADC consists of many standards of critical instruments for the conduct of credible free and fair elections for its member states. However, this has not been the case given that majority of member states in SADC are reluctant to submit themselves to the full SADC principles and guidelines on the conduct of free and fair elections. On its part, SADC simply lacks the coercive enforcement mechanisms to ensure its members comply with the regional bloc's dictates on elections. This is mainly because of the member states' unwritten but mostly observed principle of respecting the principle of "benefit of the incumbency" where SADC approach with kid gloves issues to do with electoral irregularities of a sister member state.

Another widely claimed aspect is that of 'brotherhood and solidarity' within the regional bloc who always prefer to pursue politics of solidarity camouflaged by discourses of anti-imperialism and liberation struggle solidarity. This discourse has had an appeal in SADC, given that some influential member states, notably South Africa, Angola, Namibia, Mozambique, Tanzania, and Zimbabwe, still have governments led by former liberation movements. Mugabe has primarily capitalised on this to drum up regional support even at the height of the decline of his domestic and international support. A review of SADC's principles and guidelines on the conduct of credible free and fair elections indicate that with proper enforcement mechanisms, elections could become a critical democratic conduit of installing legitimate governments in the region in general and Zimbabwe in particular.

The constitutions of all SADC member states enshrine the principles of equal opportunities and full participation of the citizens in the political process.

The development of the principles governing democratic elections aims at enhancing the transparency and credibility of elections and democratic governance as well as ensuring the acceptance of election results by all contesting parties. The regional bloc obligates the Member States to adhere to the following principles in the conduct of democratic elections: the full participation of the citizens in the political process; freedom of association; political tolerance; regular intervals for elections as provided for by the respective National Constitutions; equal opportunity for all political parties to access the state media; equal opportunity to exercise the right to vote and be voted for; independence of the Judiciary and impartiality of the electoral institutions; and voter education; acceptance and respect of the election results by political parties proclaimed to have been free and fair by the competent National Electoral Authorities under the law of the land; the challenge of the election results as provided for in the law of the land (SADC Principles and Guidelines Governing Democratic Elections, 2004). In addition member states also have their responsibilities which they are obligated to honour by SADC, among them being to take necessary measures to ensure the scrupulous implementation of the above principles, in accordance with the constitutional processes of the country; establish where none exist, appropriate institutions where issues such as codes of conduct, citizenship, residency, age requirements for eligible voters and compilation of voters' registers, would be addressed; 
Establish impartial, all-inclusive, competent and accountable national electoral bodies staffed by qualified personnel, as well as competent legal entities including effective constitutional courts to arbitrate in the event of disputes arising from the conduct of elections; safeguard the human and civil liberties of all citizens including the freedom of movement, assembly, association, expression, and campaigning as well as access to the media on the part of all stakeholders, during electoral processes; take all necessary measures and precautions to prevent the perpetration of fraud, rigging or any other illegal practices throughout the whole electoral process, in order to maintain peace and security; ensure the availability of adequate logistics and resources for carrying out democratic elections to mention a few (SADC Principles and Guidelines Governing Democratic Elections, 2004).

The above instruments, brilliant as they appear have significantly failed to be applicable in Zimbabwe, primarily because of President Mugabe's doctrine of sovereignty and territorial integrity. Serve for Botswana and South Africa; other fellow member states have remained silent on Zimbabwe's violation of the SADC Principles and Guidelines Governing Democratic Elections. This is understandable, given that majority of regional states share similar authoritarian tendencies with Zimbabwe.

\section{Zimbabwe's Electoral Infrastructure}

Section 238 of Zimbabwe's New Constitution provides the Zimbabwe Electoral Commission (ZEC) consisting of a chairperson appointed by the president after consultation with the Judicial Service Commission and the Committee on Standing Rules and Orders; and eight other members appointed by the president from a list of not fewer than twelve nominees submitted by the Committee on Standing Rules and Orders.

The functions of ZEC as provided by the Constitution are to prepare for, conduct and supervise - elections to the office of president and to Parliament, elections to provincial and metropolitan councils and the governing bodies of local authorities, elections of members of National Council of Chiefs, referendums; supervise elections of the president of the Senate and the Speaker; register voters; compile voters' rolls and registers; ensure the proper custody and maintenance of voters' rolls and registers; delimit constituencies, wards and other electoral boundaries; design, print and distribute ballot papers, approve the form of and procure ballot boxes, and establish and operate polling centres; conduct and supervise voter education; accredit observers of elections and referendums; give instructions to persons in the employment of the state or of a local authority for the purpose of ensuring the efficient, free, fair, proper and transparent conduct of any election or referendum; and to receive and consider complaints from the public and to take such action in regard to the complaints as it considers appropriate. In all these undertakings the Constitution insists that ZEC should ensure that the conduct of elections and referendums are conducted efficiently, freely, fairly, transparently and in accordance with the law.

In addition to the establishment of ZEC and its functions, Section 155 of the New Constitution establishes Zimbabwe's Electoral Systems stipulating that the elections must be held regularly, and referendums, to which the Constitution applies must be peaceful, free and fair; conducted by secret ballot; based on universal adult suffrage and equality of votes, and free from violence and other electoral malpractices. Section 155(2) of the Constitution obligates the state to take all appropriate measures, including legislative measures, to ensure that all eligible citizens are registered as voters as well as creating that opportunity for every citizen to cast a vote as well as facilitating voting by persons with disabilities or special needs.

The state is also mandated to ensure that all political parties and candidates contesting an election or participating in a referendum have reasonable access to all material and information necessary for them to participate effectively. Moreover, provide all political parties and candidates contesting an election or participating in a referendum with fair and equal access to electronic and print media, both public and private; and ensure timely resolution of electoral disputes. Whereas the above constitutional submissions are from a legal perspective sound and meaningful, the Zimbabwean experience has since reminded the world that having a brilliant constitution is one thing whilst adhering to it is another. Indeed, Zimbabwe's crisis from 1980 has never been that of a constitution but constitutionalism - that is the commitment and spirit to adhere to the dictates of a constitution.

Furthermore, the record shows that ZANU PF tendsto activate its electoral apparatus in full swing during elections. The apparatus comprises the CIO, the Army, the Police as well as the media. Whereas public media is funded publicly by the taxpayers' money, access to this platform which mostly has a broader coverage has remained a preserve only of ZANU PF. Equal opportunities in elections entail that all contestants have equitable and adequate access to the mass media and other forms of mass communication (Makumbe, 2006, p. 49).

However, this has not been the case in Zimbabwe, coverage of the opposition on national radio and television stations is mostly done in the context aimed at giving the ruling ZANU PF leverage as well as exposing the opposition as stooges of Western Imperialism. Moreover, the state-controlled media has primarily remained an extension of the ruling party's information and publicity department with the incumbent Minister of Information having influential powers to appoint and disappoint editors. 
All this is done much to the violation of the constitution as well as regional, continental, and international dictates that stipulate procedures of conducting free and fair democratic elections.

On August 3, 2013, the Zimbabwe Electoral Commission (ZEC) declared Robert Gabriel Mugabe winner of the July 31 harmonised elections with his party ZANU PF having swept a two-thirds majority in parliament. Mugabe retained the throne he has held since 1980. This has paused critical questions on whether elections in Zimbabwe a viable mechanism for the transfer of power are, reflecting people's will or just a mere constitutional formality aimed at legitimacy accumulation by ZANU PF. With no impending opposition threat, factionalism in ZANU PF manifested whose endgame was the humiliating removal of Mugabe by the military and installation of his former deputy and trusted ally Emmerson Mnangagwa as President on November 21, 2017.

In May 2018, President Mnangagwa proclaimed July 30 as the date for harmonised elections to choose the President, National Assembly members and councillors. The proclamation was made through Statutory Instrument 83 of 2018 and was published in an Extraordinary Government Gazette. For the record, the electoral contest has several political parties and 23 presidential candidates, the first of a kind since 1980. However, two leading contenders were Mnangagwa of the ruling ZANU PF and Nelson Chamisa who had taken over from Morgan Tsvangirai following the veteran opposition's death on February 14, 2018. Chamisa was rallying behind MDC Alliance - a coalition of breakaway factions of the original MDC formed in 1999. Other notable candidates were Joice Mujuru, the former ousted Mugabe's deputy and vice president of Zimbabwe, Thokozani Khupe, one of Tsvangirai's deputies and Ambrose Mutinhiri former ZANU PF minister.

The period preceding the campaign period was relatively even and hailed as one of the most peaceful following decades of bitterly contested elections marred with state-sponsored violence and intimidation. For the first time, the opposition was allowed to campaign freely without any hindrance even entering long perceived ZANU PF strongholds previously declared no go areas for the opposition. The polling day arrived, and long ques and a remarkable voter turnout characterised the election. People anxiously waited for the electoral outcome. The wait finally came to an end in the early hours of August 3 when Justice Priscilla Chigumba the Zimbabwe Electoral Commission chairperson proclaimed Mnangagwa the winner of the presidential poll after begging 2460416 votes with a $50.8 \%$ of the vote beating Chamisa who got 2147436 votes.

Before the final announcement of results, some protests had erupted in Harare's central business district. Supporters and people sympathetic to the MDC Alliance had started marching alleging vote-rigging and electoral fraud. The demonstrations resulted in property destruction and burning of cars. They also resulted in the death of six people following the deployment of the army. The police chief defended the deployment of the army saying their contingent was limited given that the majority of police officers were deployed all over the country during the voting period. Chamisa and the entire MDC Alliance rejected the result. On August 10 he filed the electoral challenge before the Constitutional Court setting aside Mnangagwa's inauguration which was slated for August 12. After cross-examining the defence team, the bench led by Chief Justice Luke Malaba upheld Mnangagwa's victory proclaimed by ZEC on August 3. In his final ruling,

Malaba said the petition by MDC Alliance leader Nelson Chamisa was deficient of evidence to buttress his litany of poll rigging claims. This marked the end of the July 30, 2018, harmonised poll at which Mnangagwa emerged the winner and eventually sworn in on August 19.

\section{Conclusion}

My conclusion is that the conduct of elections in Zimbabwe is far from mirroring the people's will exercised through a plebiscite. Given the nature of intolerance of opposition political parties and their supporters by ZANU $\mathrm{PF}$, the need for conducting general elections under the prevailing climate shall remain an exercise in futility and more of a ritual. To ZANU PF elections have become a viable mechanism to prove all and sundry that at least within the state the former liberation movement still commands overwhelming support, hence deserving legitimacy.

\section{Disclosure Statement}

The author reported no potential conflict of interest.

\section{References}

Alao, A. (2012). Mugabe and the Politics of Security in Zimbabwe. Ontario: MQUP.

Catholic Commission for Justice and Peace in Zimbabwe(1997). Breaking the Silence Building True Peace, A report on the disturbances in Matabeleland and the Midlands 1980 to 1988. Harare: The Legal Resource Foundation.

Chimanikire, D. P. (2003). "Foreign and Security Policy: From Independence to the DRC". In Darnolf, S., and Laasko, L. (Eds). Twenty Years of Independence in Zimbabwe, From Liberation to Authoritarianism. New: Palgrave Macmillan.

Constitution of Zimbabwe Amendment No. 20 
Cowen, M \& Laasko, L, (2002), Multi-Party Elections in Africa. Oxford, James Currey.

Flower, K. (1987). Serving Secretly - An Intelligence Chief on Record Rhodesia into Zimbabwe 1964 to 1981. London: John Murray.

Heywood, A. (2007). Politics (third edition). England: Palgrave McMillan.

Klotz, A. (1993). 'Race and nationalism in Zimbabwe's foreign policy,' The Roundtable: The Commonwealth Journal of International Affairs: Vol. 82, number 327. pp. 255-279.

Makumbe, J. (2006). 'Electoral Politics in Zimbabwe: Authoritarianism Versus the People'. African Development. Vol. XXXI, No. 3. pp. $45-61$.

Mamdani, M. (1990). 'State and Civil Society in Contemporary Africa: Conceptualising the Birth of State Nationalism and the Defeat of Popular Movements. Africa Development: CODESRIA, Dakar.

Moyo, JN (1992). Voting for Democracy: Electoral Politics in Zimbabwe. Harare: University of Zimbabwe Publications.

Nyakudya, M. (2013). Sanctioning the Government of National Unity: a review of Zimbabwe's relations with the West in the framework of the GPA. In B Raftopolous (ed), The Hard Road to Reform: The Politics of Zimbabwe's Global Political Agreement. Harare: Weaver Press.

Phimister, I., and Raftopolous, B. (2004). 'Mugabe, Mbeki and the politics of anti-imperialist'. Review of African Political Economy. Vol. 3, No. 1(101), pp. 385.

Rusero, A. M. (2016). Module in Zimbabwe's History, Pre-colonial to present. Harare: Harare Polytechnic Publications.

Sithole, M., \& Makumbe, J. (1997) 'Elections in Zimbabwe: The ZANU (PF)

Hegemony and Its Incipient Decline, in African Journal of Political Science, 2 (1): 122

139.

United States Institute of Peace, Special Report. Zimbabwe and the Prospects for Nonviolent Political Change. End Notes www.usip.org. [accessed. February 1, 2017].

\footnotetext{
${ }^{\mathrm{i}}$ Zimbabwe was colonised by the British in 1890 through Cecil John Rhodes to which the colony (Rhodesia) was named after his name. Until 1980 general elections were held after a Lancaster House Ceasefire Agreement, the state remained a British colony.

${ }^{\mathrm{ii}}$ The Unilateral Declaration of Independence was a self-proclamation of an independent sovereign state by the Rhodesian government in November 1965. UDI was widely regarded as illegal and lacked recognition for the 15 years it was in existence until the 1980 general elections.

iii Gukurahundi was originally a term coined by ZANU to refer to 1979 as the Year of People's Storm which would determine the course of independence through the liberation struggle. Gukurahundi later manifested as ZANU 's strategy of annihilating its enemies as witnessed between 1982 and 1987 where the ZANU-led government in an independent Zimbabwe unleashed a special armed force to deal with 'dissidents' who were ZAPU supporters in the Midlands and Matabeleland Provinces.

${ }^{\text {iv }}$ Chimurenga is a Shona term referring to war. It is here used to understand ZANU PF's liberation struggle logic which it has characterise $d$ as an endless struggle starting with Chimurenga 1 (1896-1897); Chimurenga 2 (The liberation struggle that took place between 1966 and 1979) and Chimurenga 3 (ZANU PF's characterisation of its land redistribution programme as another version of an economic war).
} 